\title{
Uşak İlinde Meydana Gelen Trafik Kazalarının İncelenmesi
}

\author{
Jülide Öner $^{1 *}$, Halil Ersoysal ${ }^{2}$ \\ 1* Uşak Üniversitesi, Mühendislik Fakültesi, İnşaat Mühendisliği Bölümü, Uşak, Türkiye, (ORCID: 0000-0003-3229-152X), julide.oner@usak.edu.tr \\ ${ }^{2}$ Uşak Üniversitesi, Lisansüstü Eğitim Enstitüsü, İnşaat Mühendisliği Bölümü, Uşak, Türkiye (ORCID: 0000-0003-1598-9010), halilersoysal@gmail.com
}

(İlk Geliş Tarihi 17 Eylül 2021 ve Kabul Tarihi 3 Kasım 2021)

(DOI: $10.31590 /$ ejosat.996702)

ATIF/REFERENCE: Öner, J. \& Ersoysal, H. (2021). Uşak İlinde Meydana Gelen Trafik Kazalarının İncelenmesi. Avrupa Bilim ve Teknoloji Dergisi, (31), 298-308.

\begin{abstract}
Öz
Araç sahipliğinde günden güne meydana gelen artış, trafik kaza oranlarında da artışları beraberinde getirmektedir. Artan araç sayısı, trafik güvenliğinin azalmasına dolayısıyla trafikte meydana gelen ölümlü, yaralanmalı ve maddi hasarlı kazaların artmasına sebep olmaktadır. Bu çalışma kapsamında D300 karayolunun Uşak ili sınırları içerisindeki kesiti üzerinde meydana gelen kazalar incelenmiştir. Uşak Emniyet Müdürlüğü, Trafik Tescil Ve Denetleme Şube Müdürlüğü’nden temin edilen verilerden yola çıkarak Uşak ili için araç sahipliği, D300 yolundaki kazaların il geneli kazalarla karşılaştırılması ve D300 karayoluna ait kaza koordinatlarının incelenmesi ele alınmıştır. Kaza koordinatlarına göre yoğunluğun yüksek olduğu bölgelerde; trafik güvenliğinin artırılması, ölümlü, yaralanmalı ve maddi hasarlı kazaların önlenebilmesi adına yeni yapı imalatları (battı-çıktı uygulaması), üst geçit uygulamaları, yaya geçişini kontrol altına alma amacıyla orta kaldırıma set çekme uygulamaları, yol geometrisi düzenleme gibi uygulamaların varlığı tespit edilmiştir. Kaza sayısı yüksek olan; Hacıkadem Kavşağı, Dikilitaş Kavşağı, 15 Temmuz Mehmet Çetin Köprülü Kavşağı ve öncesi 1. Bölüm, Dörtyol Kavşağı ve Belediye Cami Kavşağı bölgeleri için alınan önlemlerin etkinliğini arttırmak amacıyla hız sınırlandırma çalışmasının yapılması gerekli görülmüştür. D300 karayolunun etkinliği göz önüne alınarak kasis ve trafik 1şığı gibi hız sınırlama yöntemlerinden ziyade son yıllarda kullanımı yaygınlaşan ortalama hız koridoru uygulamasının tercih edilmesi gerektiği düşünülmektedir.
\end{abstract}

Anahtar Kelimeler: Trafik kazaları, D300 karayolu, Trafik güvenliği, Hız koridoru, Yüksek hız.

\section{Investigation of Traffic Accidents in the Province of Ușak}

\begin{abstract}
The increase in car ownership from day to day also leads to an increase in traffic accident rates. Increasing number of vehicles, reduced traffic safety, resulting in traffic fatalities, injuries and property damage causes an increase in accidents. As part of this study, the crosssection of the D300 highway in the border of Uşak province the accidents that occurred were investigated. Based on the data provided by Uşak Police Department Traffic Registration and Supervision Branch Directorate; vehicle ownership for Uşak province, accidents on D300 road comparison of accidents in general and investigation of accident coordinates were tried to be determined. In areas where the intensity is high according to accident coordinates; new constructions manufacturing (sunk out road application), upper crossing applications, middle lift set towing applications to take the pedestrian crossing under the control, road geometry alignment have been identified in the name of increasing traffic safety, enabling fatal, injured and property damage accidents. High number of accidents; Hacıkadem Junction, Dikilitaş Junction, 15 Temmuz Mehmet Çetin Bridge Junction and before 1. Section, Dörtyol Junction and Municipal Mosque Junction in order to increase the effectiveness of the measures taken for their regions, it was necessary to conduct a speed limit study.
\end{abstract}

Keywords: Traffic accidents, D300 highway, Traffic safety, Speed corridor, High speed.

*Sorumlu Yazar: julide.oner@usak.edu.tr 


\section{Giriş}

Dünyada ve ülkemizde karayolu trafiğindeki araç sayısı her geçen gün artmakta bu da beraberinde karayollarında istenmeyen trafik sıkışıklıklarına sebep olmaktadır (Tenekeci, 2019). Karayolu taşıyıcılığı açısından bakıldığında ülkemizde ulaşım ve taşıma hizmetlerinin \%95'e yakını karayolu ile yapılmaktadır (Ulaştırma Özel İhtisas Komisyonu Raporu Trafik Düzeni, 2001). Her geçen gün artan değerlere ulaşan trafik yoğunluğu sonucu trafik güvenliğinin önemi artmaktadır (Civcik ve Koçak, 2020). Trafik yoğunluğunun azaltılmasının çevresel ve ekonomik olarak birçok faydası bulunmaktadır (Güneş ve ark., 2020). Trafikte meydana gelen yoğunluk sürücülerin trafik kurallarını ihlal eğilimlerinin artmasına sebep olmaktadır (Aydın, 2017). Trafik güvenliğini tehdit eden unsurların en başında aşırı hız gelmektedir. Aşırı hız kavramı karayolu için belirlenen hız limitlerinin sürücüler tarafından ihlal edilerek yüksek hızlarda hareket edilmesi anlamına gelmektedir. Karayollarında yolun bağlı olduğu kamu idaresince hız limitleri belirlenmektedir. Sürücüler tarafından hız limitlerinin üzerinde hareket etmeler sonucu şehir içi ve şehirlerarası yollarda birçok ölümlü ve yaralanmalı kaza meydana gelmektedir (Ng ve Small, 2012).

Meydana gelen trafik kazaları sonucu can kayıları yaşanması ve yaralanmaların meydana gelmesi yanı sıra maddi hasarlı kazalar ile ekonomik kayıplar yaşanmaktadır. Kazalar sonucu kişiler üzerinde ruhsal yönden stres bozukluğu durumları görülebilmektedir. Ayrıca sosyo-ekonomik yönden olası uzun süreli tedavi masrafları, üretim kayıpları, kurtarma ve polislik hizmetleri için harcanan zaman gibi kayıplar söz konusu olmaktadır (Europan Transport Safety Council, 2007).

Dünya'da ve Türkiye'de aşırı hızdan kaynaklanan kazaların yüksek orana sahip olmasından dolayı gerek araştırmacılar gerekse yetkililer tarafından bu problemin çözümüne yönelik çalışma yapma gereksinimi ortaya çıkmıştır. Ülkeler çeşitli hız denetim sistemleri üzerinde çalışarak trafikteki yüksek hız problemini çözmek istemektedir. Radar cihazı ve polis denetimi sistemi bu sistemlerden en yaygını olarak tercih edilmektedir (Goldenbeld ve Van Schagen, 2005). Radarla hız denetimi birçok ülkede tercih edilen bir denetim sistemidir. Radarla hız denetimi Türkiye'de de şehir içi ve şehirlerarası hız denetiminde uygulanan bir sistemdir (Şahin, 2004). Bu sistem işleyiş olarak belli bir izleme noktasında duran ekip aracı ile yoldan geçen araçların hız değerlerinin tespit edilmesi ve belirlenen hız limitlerinin üzerinde olması durumunda cezai işlem uygulanması esasına dayanmaktadır. Ancak sistemin dezavantajı noktasal olmasıdır. Sürücüler tarafından radar sisteminin yerinin bilinmesi durumunda, bilinen bölgede hızlar azaltılarak hız ihlali yapma durumu ortadan kaldırılmış olacak ve ceza uygulamasından kaçılmış olunacaktır. $\mathrm{Bu}$ sistemle amaçlanan esas olarak sürücülere ceza uygulamak olmamakla beraber belirlenen hız limitlerine uyumu arttırarak trafik güvenliğini sağlamak ve aşırı hıza bağlı oluşacak kazaların önlenmesini sağlamaktır. Bu sistem ile karayolu üzerinde süreklilik sağlayacak şekilde denetim oluşturabilmek için çok sayıda tespit noktası ve bu noktalar içi gerekli yetkili kişiler, araç vb. kaynaklara ihtiyaç duyulmaktadır.

Trafik güvenliği için yapıla yatırımlar ülkemizdeki araç sahipliği ve nüfus artışının gerisinde kalmasından dolayı trafik polislerinin vakit ve imkânları trafiğgin yönetilmesine ve akışına harcanmaktadır (Ilgaz ve Saltan, 2017). Yapılan denetimlerde standartlar sağlanamadığından dolayı sürücüler tarafindan hız ihlalleri gerçekleştirilmektedir. Mevcut sistem ile ceza uygulamasında eşitlik ve adaletten uzaklaşılmakta olup bu sistemde amaç sürücülere ceza uygulamak değil trafik kazalarını ve bunlara bağlı ölümlü ve yaralanmalı kazaları önlemektir (Acar, 2009).

Son yıllarda ülkemiz genelinde yapılan araştırmalarda meydana gelen kazaların $\% 90$ oranında sürücülerden kaynaklandığını göstermektedir (Ilgaz, 2017). Tablo 1'de 20102019 yılları arasında meydana gelen ölümlü ve yaralanmalı trafik kazalarındaki kusur oranları ve Tablo 2'de ölümlü ve yaralanmalı trafik kazalarına etken sürücü bilgileri sunulmaktadır. Tablo 1 ve Tablo 2'de sunulduğu üzere meydana gelen kazaların içinde yüksek hızdan kaynaklananların oranı yaklaşık \%40’tır (Cavdar ve ark., 2008).

Tablo 1'de görüldüğü üzere son y1llarda meydana gelen ölümlü ve yaralanmalı trafik kazalarında insan faktörü \%99 gibi önemli bir oran teşkil etmektedir. Sürücülerin yüksek kaza oranına neden olan kusur dağılımı Tablo 2'de sunulmaktadır.

Tablo 1. Yıllar itibariyle meydana gelen ölümlü ve yaralanmalı trafik kazalarındaki kusur oranları 2010-2019 (KGM, 2019)

\begin{tabular}{|c|c|c|c|c|c|c|}
\hline \multirow[b]{2}{*}{ Yıllar } & \multicolumn{4}{|c|}{$\begin{array}{c}\text { INSAN } \\
\text { FAKTÖRÜ }\end{array}$} & \multirow[b]{2}{*}{$\begin{array}{c}\text { Taşıt } \\
\%\end{array}$} & \multirow[b]{2}{*}{$\begin{array}{c}\text { Yol } \\
\%\end{array}$} \\
\hline & $\begin{array}{c}\text { Sürücü } \\
\%\end{array}$ & $\begin{array}{c}\text { Yaya } \\
\%\end{array}$ & $\begin{array}{c}\text { Yolcu } \\
\% \\
\end{array}$ & $\begin{array}{c}\text { Toplam } \\
\% \\
\end{array}$ & & \\
\hline 2010 & 89,72 & 8,97 & 0,36 & 99,05 & 0,33 & 0,63 \\
\hline 2011 & 90,20 & 8,51 & 0,39 & 99,10 & 0,30 & 0,60 \\
\hline 2012 & 88,86 & 9,75 & 0,44 & 99,05 & 0,33 & 0,62 \\
\hline 2013 & 88,97 & 8,91 & 0,43 & 98,31 & 0,92 & 0,77 \\
\hline 2014 & 89,12 & 9,21 & 0,48 & 98,81 & 0,62 & 0,58 \\
\hline 2015 & 89,76 & 8,67 & 0,45 & 98,88 & 0,58 & 0,54 \\
\hline 2016 & 90,02 & 8,60 & 0,41 & 99,03 & 0,50 & 0,46 \\
\hline 2017 & 90,29 & 8,35 & 0,37 & 99,01 & 0,55 & 0,45 \\
\hline 2018 & 89,64 & 8,28 & 1,09 & 99,01 & 0,64 & 0,35 \\
\hline 2019 & 88,89 & 7,92 & 0,85 & 97,65 & 2,05 & 0,30 \\
\hline
\end{tabular}




\begin{tabular}{|c|c|c|c|c|c|c|}
\hline \multirow{2}{*}{ SÜRÜCÜ KUSURLARI } & \multicolumn{2}{|c|}{ Yerleşim Yeri } & \multicolumn{2}{|c|}{ Yerleşim Yeri Dışı } & \multicolumn{2}{|l|}{ TOPLAM } \\
\hline & $\begin{array}{l}\text { Kusur } \\
\text { Sayıs }\end{array}$ & $\%$ & $\begin{array}{l}\text { Kusur } \\
\text { Sayısı }\end{array}$ & $\%$ & Kusur Sayısı & $\%$ \\
\hline $\begin{array}{l}\text { Araç hızını yol, hava ve trafiğin gerektirdiği şartlara } \\
\text { uydurmamak }\end{array}$ & 48566 & 35,63 & 23166 & 47,98 & 71732 & 38,86 \\
\hline Kavşak, geçiş önceliğine uymamak & 24287 & 17,82 & 2779 & 5,76 & 27066 & 14,66 \\
\hline Şerit ihlali yapmak & 10023 & 7,35 & 7951 & 16,47 & 17974 & 9,74 \\
\hline Arkadan çarpmak & 11313 & 8,30 & 4893 & 10,13 & 16206 & 8,78 \\
\hline Doğrultu değiştirme (dönüş) kurallarına uymamak & 11827 & 8,68 & 1568 & 3,25 & 13395 & 7,26 \\
\hline Manevraları düzenleyen genel şartlara uymamak & 7078 & 5,19 & 1539 & 3,19 & 8617 & 4,67 \\
\hline Kırmızı 1ş1k veya görevlinin dur işaretine uymamak & 4600 & 3,37 & 990 & 2,05 & 5590 & 3,03 \\
\hline Taşıt giremez trafik işareti bulunan yerlere girmek & 4145 & 3,04 & 666 & 1,38 & 4811 & 2,61 \\
\hline Trafik güvenliği ile ilgili diğer kurallara uymamak & 3258 & 2,39 & 559 & 1,16 & 3817 & 2,07 \\
\hline Alkollü olarak araç kullanmak & 2018 & 1,48 & 1098 & 2,27 & 3116 & 1,69 \\
\hline $\begin{array}{l}\text { Yaya ve okul geçitlerinde yavaşlamamak, yayalara } \\
\text { geçiş hakk1 vermemek }\end{array}$ & 2287 & 1,68 & 46 & 0,10 & 2333 & 1,26 \\
\hline Aşırı hızla araç kullanmak & 1090 & 0,80 & 887 & 1,84 & 1977 & 1,07 \\
\hline Geçme yasağı olan yerlerden geçmek & 1007 & 0,74 & 347 & 0,72 & 1354 & 0,73 \\
\hline Hatalı şekilde veya yasak olan yerlere park etmek & 369 & 0,27 & 594 & 1,23 & 963 & 0,52 \\
\hline Kurallara uygun olarak park etmiş araçlara çarpmak & 649 & 0,48 & 107 & 0,22 & 756 & 0,41 \\
\hline $\begin{array}{l}\text { Eksik, bozuk veya uygun olmayan araç donanımıyla } \\
\text { araç kullanmak }\end{array}$ & 235 & 0,17 & 286 & 0,59 & 521 & 0,28 \\
\hline Yolcu indirme ve bindirme kurallarına uymamak & 458 & 0,34 & 25 & 0,05 & 483 & 0,26 \\
\hline $\begin{array}{l}\text { Bisiklet, M.bisiklet ve Motosikletleri kurallara } \\
\text { uymadan sürmek }\end{array}$ & 466 & 0,34 & 16 & 0,03 & 482 & 0,26 \\
\hline Tehlikeli veya aşırı şekilde yükleme yapmak & 204 & 0,15 & 176 & 0,36 & 380 & 0,21 \\
\hline $\begin{array}{l}\text { Kaza mahallinde durmamak, gerekli tedbirleri almamak } \\
\text { ve yetkililere bildirmemek }\end{array}$ & 155 & 0,11 & 61 & 0,13 & 216 & 0,12 \\
\hline Diğer & 2.285 & 1,68 & 527 & 1,09 & 2.812 & 1,52 \\
\hline TOPLAM & 136320 & 100 & 48281 & 100 & 184601 & 100 \\
\hline
\end{tabular}

Tablo 2'deki diğer kusurlar göz önüne alındığında birçok kusurun dolaylı sebebi olarak hız ihlallerinin varlığ düşünülebilmektedir. Belirlenen hız limitlerine uymanın, ölümlü ve yaralanmalı kazaları önlemede yapılacak en önemli davranış olacağı önerilmektedir. Sürüş hızı ne kadar yüksek olursa kazaya karışma riski de o kadar yüksek olmaktadır. Sürücü ortalama hızın altında kalırsa kaza riski de azalmaktadır (Vadeby ve Forsman, 2014). Trafikte meydana gelen kazaların hızın büyüklüğüyle ilgili olduğu düşünülmektedir. Yapılan incelemeler trafik kazalarındaki hızın 2. kuvvetiyle yaralanmalı kaza sayısı, 3. kuvvetiyle ağır yaralanmalı kaza sayısı ve 4. kuvvetiyle ölümlü kaza sayıs1 arasında orantı olduğunu göstermektedir (Aldoğan, 1991). Ayrıca ölüm oranlarındaki \%3'lük artışın ortalama hızdaki $1 \mathrm{~km} / \mathrm{sa}$ 'lik artış sonucu oluştuğu görülmektedir (Elvik, 1999). Yüksek hızların kaza ile ilişkisi hızın yükseklik değerinin artmasıyla paralellik izlemektedir. Benzer şekilde yapılan tahminlere göre ortalama hızdaki $5 \mathrm{~km} / \mathrm{sa}$ 'lik azalma yılda Avrupa Birliği'ne üye e-ISSN: 2148-2683 ülkelerde 11,000 kişinin ölümden ve 180,000 kişinin yaralanmaktan kurtulabileceğini ön görmektedir (Türkiye Şoförler ve Otomobilciler Federasyonu, 1997). Hız ve kaza riski arasındaki ilişki karmaşık olmasına rağmen kayda değer sayıdaki araştırma sonucu daha düşük hızlardaki araçların daha az kaza meydana getirdiğini ve meydana gelen kazalarda da daha az kaybın yaşandığını göstermektedir (Jones ve ark., 2008).

$\mathrm{Bu}$ araştırma kapsamında, Uşak ili sınırları içerisinde yer alan D300 karayolu üzerindeki trafik yoğunluğu yüksek olan on beş adet dügüum noktasındaki son beş yıla ait trafik kaza koordinatları ve türleri belirlenerek kaza istatistikleri oluşturulmuştur. Bölgesel materyallerin ele alındığı bu çalışmada, trafik güvenliği sağlamak ve ölümlü, yaralanmalı, maddi hasarlı kazaları önlemek adına sağlayacağı katkılar ve öneriler sunulmuştur. Uşak ili sınırları içerisinde yer alan D300 karayolu üzerinde meydana gelen aşırı 
hıza bağlı kazaların sayısı ile can ve mal kayıplarının oluşması çalışmayı gerekli kılmaktadır.

\section{Materyal ve Metot}

Trafik, karayolu üzerindeki yaya ve taşıtların her türlü hal ve hareketi olarak tanımlanmaktadır. Yaya faktörü içerisine insan ve diğer canlı gruplarını alırken taşıtlar özelliklerine göre farklı kategorilerde sınıflandırılmaktadır. Bu bağlamda trafik içerisinde oluşturulan akışın kusursuza yakın şekilde sağlanması için başlıca etken trafik güvenliğinin azami düzeyde sağlanması olmaktadır. Trafik güvenliğinin sağlanarak ölümlü, yaralanmalı ve maddi hasarlı kazaların önlenmesi amacıyla birtakım güvenlik tedbirleri geliştirilmektedir.

Ankara-İzmir yolu istikametinde yer alan Uşak ili ülkemizin gelişmişlik ve nüfus yönünden büyük illerinden ikisi olan İzmir'den Ankara'ya gidiş ve dönüş yolu üzerinde olması sebebiyle yüksek trafik yoğunluğuna sahip durumdadır. Ayrıca ülkemizin önemli deniz ticareti ve turizm noktası olan İzmir iline Karadeniz, Doğu Anadolu, İç Anadolu, Güney Doğu Anadolu ve Akdeniz Bölgesi'nin doğu kesimleri ile trafik bağlantısı sağlamaktadır. $\mathrm{Bu}$ bağlantı da Uşak ili içinde yer alan karayolunun kapasitesine yansımaktadır. Şehir içi ve şehirlerarası trafik akışının büyük çoğunluğunun D300 karayolunda meydana gelmesinden dolayı yol üzerinde kazaların olma ihtimali artmaktadır.
D300 karayolu üzerinde trafik güvenliğini sağlayarak ölümlü ve yaralanmalı kaza oranlarının düşürülmesi amacı doğrultusunda seçilecek verilerin güvenli olması adına hassas davranılması gerekmektedir. Karayolunun mevcut durumunda trafik yoğunluğunun yüksek oluşu, araç sahipliğinin artışı ve ilerleyen dönemde trafik akışındaki yoğunluğun daha da artacak olması gibi sebepler neticesinde veri seçiminin önemi de artmaktadır.

Günümüz şartları altında gerçekleşen trafik kazalarında şehir içi trafik akışında önemli paya sahip olan, kullanımı diğer yol ağlarına göre daha fazla olan yol hatlarında emniyet yetkililerinin kazalara müdahale etmesi, kazaların sebep-sonuç ilişkisini sağlıklı değerlendirmesi ve istatistikî veri oluşturması daha nitelikli şekilde yapılmaktadır. Kapsamlı trafik kaza analizlerinin yapılması ve veriye dönüştürülmesi önem arz etmektedir.

Şekil 1'de D300 Karayolu üzerinde yer alan kaza yoğun bölgeler verilmiş olup bölgelerin isimleri sırasıyla şu şekildedir: Uşak Üniversitesi Kavşağı, Hacıkadem Kavşağı, Şehit Yener Sunal Üst Geçidi, Dikilitaş Kavşağı, 15 Temmuz Mehmet Çetin Köprülü Kavşağı Öncesi 1. Bölge, 15 Temmuz Mehmet Çetin Köprülü Kavşağı Öncesi 2. Bölge, 15 Temmuz Mehmet Çetin Köprülü Kavşağı, Osmanlı Köprülü Kavşağı Öncesi Bölüm, Osmanlı Köprülü Kavşağı, Dörtyol Kavşağı, Belediye Cami Kavşağı, Selçuklu Köprülü Kavşağı, 1 Eylül Sanayi Kavşağı, Uşak Eğit. Araş. Has. Kavşağı, Hava Limanı Kavşağı.

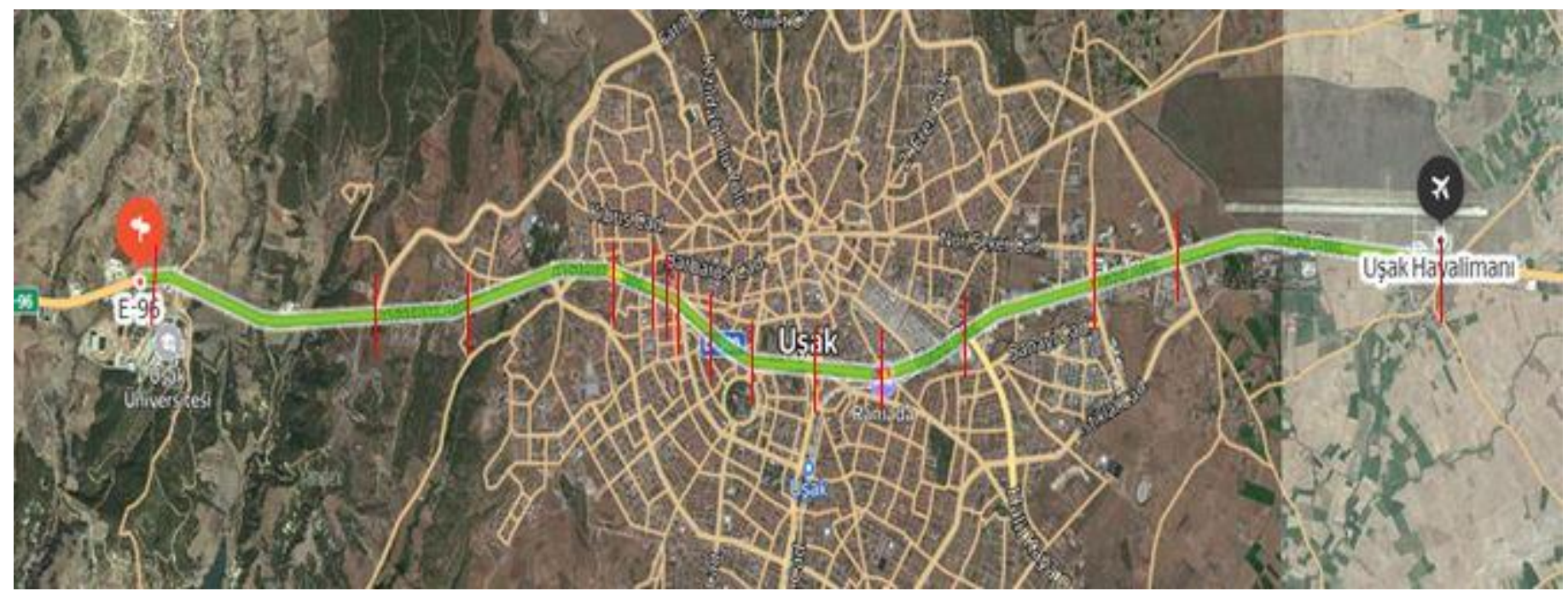

Şekil 1. D300 Karayolu üzerinde yer alan kaza yoğunluklu bölgeler

\section{Araştırma Sonuçları ve Tartışma}

Trafik durumu ile ilgili genel olarak bilgi aktarılan Uşak ili D300 karayolu için bu bölümde, Uşak Emniyet Müdürlüğü Trafik Tescil Ve Denetleme Şube Müdürlüğü'nden elde edilen verilerin çeşitliliğine göre kaza koordinatları ele alınmıştır. Yapılacak olan veri analizleri sonucunda aşırı hıza bağlı trafik kazaların önlenmesi, trafik güvenliğinin sağlanması, can ve mal kayıplarının önüne geçilmesi hedeflenmektedir.

Elde edilen veriler doğrultusunda Uşak ilinde D300 karayolunda meydana gelen kazaların genel verileri incelendiğinde kaza sayılarından önce il genelinde araç sahipliği durumunun yüksek oluşu göze çarpmaktadır. Türkiye geneli araç sahipliği durumu ve Uşak geneli araç sahipliği durumu aşağıdaki Tablo 3'te sunulmaktadir. 
Tablo 3. Uşak ve Türkiye geneli araç sahipliği(Trafik Tescil ve Denetleme Şube Müdürlüğü, 2020)

\begin{tabular}{c|c|c|c}
\hline \multicolumn{2}{c|}{ Uşak İl Merkezi Nüfus Araç Oranı } & \multicolumn{2}{c}{ Türkiye Geneli Nüfus Araç Oranı } \\
\hline Nüfus & Araç & Nüfus & Araç \\
\hline 256669 & 105249 & 83154997 & 24418987 \\
\hline \multicolumn{2}{c|}{2,44 kişiye bir araç düşmektedir } & \multicolumn{2}{|c}{3,41 kişiye bir araç düşmektedir } \\
\hline
\end{tabular}

Tablo 3’teki veriler irdelendiğinde Türkiye genelindeki kişiye düşen araç sayısına göre Uşak ilinde kişiye düşen araç sayısı daha düşüktür. $\mathrm{Bu}$ durum Uşak ili için Türkiye ortalamasının üstünde araç sahipliği olduğunu dolayısıyla trafik yoğunluğunun da fazla olduğunu göstermektedir.

Elde edilen diğer veriler arasında son 5 yıl içinde il genelinde meydana gelen trafik kazalarının listesi bulunmaktadır. Liste içerisinde yer alan sayılara göre son 5 yılda 5463 trafik kazası meydana gelmekle beraber bu kazaların içerisinde 66 tanesi ölümle sonuçlanmıştır. Gerçekleşen 66 ölümlü kazada toplam 75 vatandaşımız can kaybı yaşamıştır. Yine bu 5463 kazanın 5397 adedi de yaralanmalı kaza grubuna girmektedir. Gerçekleşen 5397 yaralanmalı kazada 9100 vatandaşımız yaralanmıştır.

Ölüm ve yaralanma sayıları ele alınarak hesaplama yapıldığında yıllık bazda ortalama 1093 kaza meydana gelirken 1820 vatandaşımız yaralanmakta ve 15 vatandaşımız hayatını kaybetmektedir.

Tablo 4. Son beş ylla ait Uşak ili kaza istatistikleri (Trafik Tescil ve Denetleme Şube Müdürlü̆üü, 2020)

\begin{tabular}{l|c|c|c|c|c}
\hline & Toplam kaza & Ölümlü kaza sayıs1 & Ölüm sayıs1 & Yaralanmalı kaza & Yaralanma sayıs1 \\
\hline İl geneli & 5463 & 66 & 75 & 5397 & 9100 \\
\hline D300 & 1453 & 43 & 51 & 1410 & 3114 \\
\hline İl geneli/D300 & $\% 26,6$ & $\% 65,2$ & $\% 68$ & $\% 26,1$ & $\% 34,2$ \\
\hline
\end{tabular}

Uşak ili kaza raporlarının genel listesi içerisinden daraltılarak elde edilen D300 karayoluna ait kazaların, Uşak Emniyet Müdürlüğü Trafik Tescil ve Denetleme Şube Müdürlüğü'nce paylaşılan koordinatları dikkate alınarak yerel karayolu ağı üzerine yerleştirilmektedir. Hazırlanan karayolu ağı üzeri kaza koordinatları görselinin kazaların yoğunlaşma noktalarının
Listelenen veriler arasında D300 karayolu için verilerin daraltılması sonucu ortaya çıkan alt veri grubu için gerçekleşen 66 ölümlü kazanın 43 adedinin ve 75 can kaybının 51 adedinin D300 karayolu üzerinde meydana geldiği görülmektedir. Tablo 4 'te veriler arası ilişkiler sunulmaktadır.

Tablodaki veriler incelendiğinde D300 karayolu üzerinde meydana gelen kazaların, tüm kazaların \%26,6'sını oluşturmasına rağmen ölümlü kaza sayısında $\% 65,2$ ve ölüm sayısında $\% 68$ gibi oldukça yüksek yüzdelik oranlara sahip olduğu görülmektedir. D300 karayolu üzerinde gerçekleşen yaralanmalı kaza sayısı ve yaralanma sayısı toplam kaza yüzdesine benzer oranlar göstermektedir.

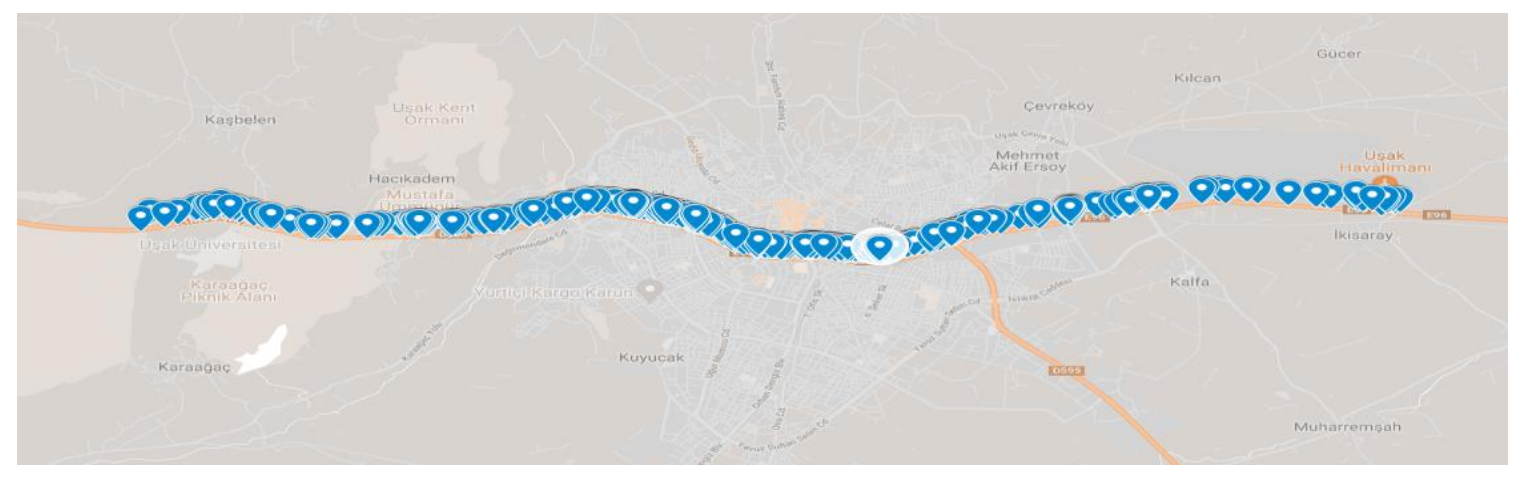

Şekil 2. D300 Karayolu Genel Kaza Koordinatları 
D300 karayolu üzerindeki genel kaza koordinatları gösterilmiş olup bölgesel olarak trafik kazalarının yoğunlaştığ yerler ayrıntı olarak ele alınmaktadır. Trafik kaza bölgelerinin incelenmesine, Uşak Üniversite yol ayrımı bölgesinden başlanarak Batı-Doğu doğrultusunda ilerlenip D300 yolu için kazaların yoğunlaştığı son nokta olarak Uşak Havalimanı bölgesinde son verilmesi planlanmaktadır. Bölgesel olarak yerleştirilen koordinatlar üzerinden sayımlar toplam kaza sayıları grafiği Şekil 3'te gösterilmektedir ve düğüm noktalarının isimlendirme aşamasında bölgedeki çevresel yapılar ve resmi kayıtlardaki isimler dikkate alınmaktadır.

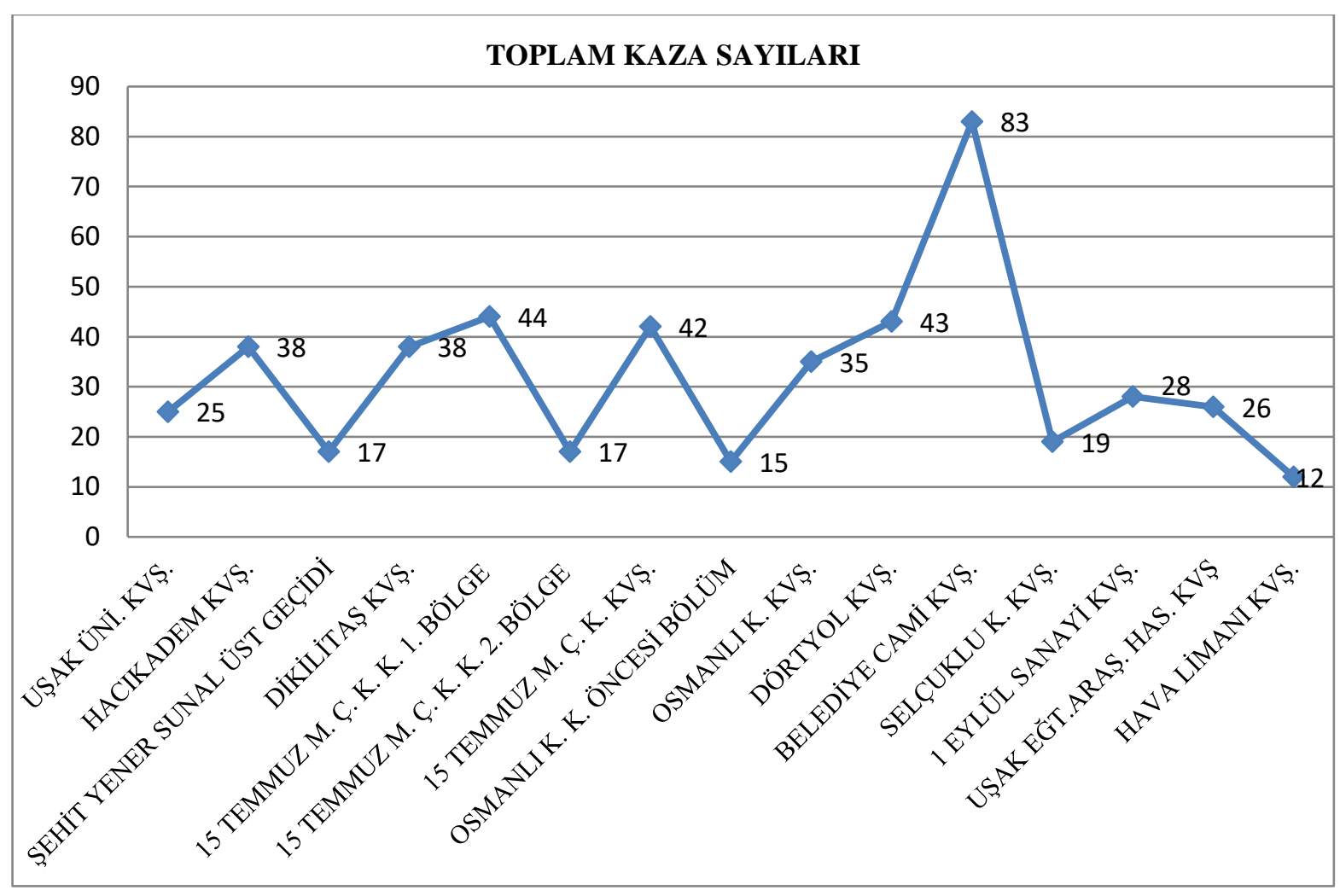

Şekil 3. D300 karayolu koordinatlara göre toplam kaza sayıları

Şekil 3'te yer alan kaza sayıları değerlerine bakılarak 35-45 aralığındaki değerler üst bölüm, 20-30 aralığındaki değerler orta bölüm, 0-20 aralığındaki değerler alt bölüm olarak ele alınmaktadır. Üst bölüm içerisinde yer alan bölgelerde kaza sayılarının yüksek olmasının sebepleri arasında kontrolsüz yaya geçişi olması, yüksek yoğunlukta trafiğe sahip yan bağlantı yollarının bulunması, alt-üst geçitlerden transit geçişten dolayı hızın yüksek olması gibi sebepler sayılabilmektedir. $\mathrm{Bu}$ sebeplerden bazıları yol geometrisine bağlı olmakla beraber diğerleri de hız faktörüyle ilişkilendirilmektedir.

D300 karayolu üzerinde meydana gelen trafik kazası verilerine göre yoğunlaşma olan bölgeler için ilk olarak üniversiteye ayrılan yol bölgesi ele alınmaktadır. Üniversite bölgesine ait 2015-2020 yılları arasında meydana gelen kazaların grafiği Şekil 4'te verilmektedir. Seçilen bölgede üniversite için iki yönden de sağdan ayrılış şeklinde yol bağlantısı olmakla beraber kazaların çoğunluğu ana yol üzerinde meydana gelmektedir. Karşıdan karşıya geçişler için oluşturulmuş çift şeritli araç üst geçidi bölgede geçişi sağlamaktadır. Şehir merkezine yaklaşık 10 km uzaklıkta bulunan üniversite yol ayrım bölgesi öncesinde herhangi bir 1şıklı trafik sistemi bulunmamakta iken sonrasındaki ilk 1şıklı trafik sistemi yaklaşık 2,1 km uzaklıktaki Hacıkadem kavşağı bölgesinde bulunmaktadır.

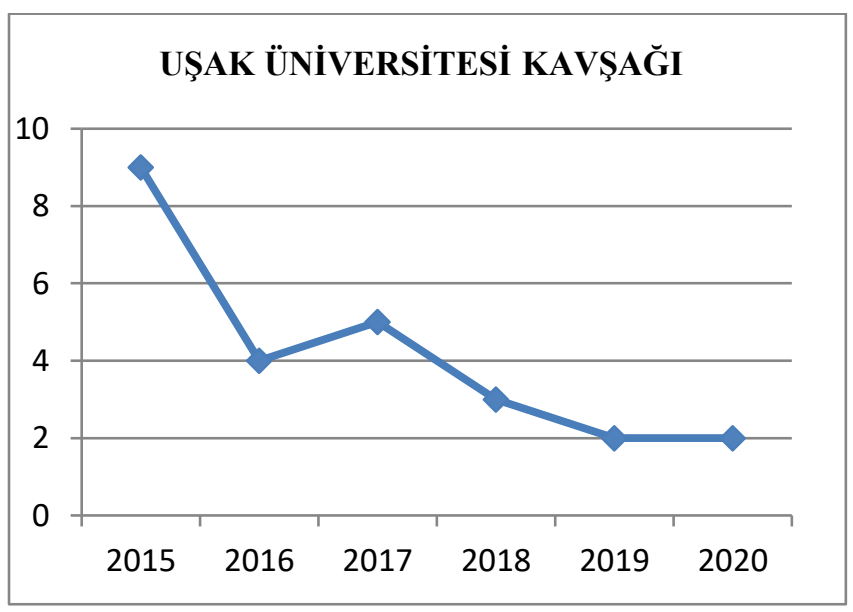

Şekil 4. Uşak Üniversitesi kavşağı bölgesi meydana gelen kazalar

Şekil 4'te görüldüğü üzere bölgede meydana gelen trafik kazalarının azalma eğiliminde olduğu görülmektedir. Toplam kaza sayıları grafiğinde orta bölümde yer almaktadır. Kazaların düşüş göstermesinde yol geometrisinde ve bağlantılarında yapılan iyileştirmeler rol oynamaktadır. 
Hacıkadem kavşağı bölgesi için gerçekleşen kazalar Şekil 5 'te gösterilmektedir. Seçilen bölge şehir merkezine $4 \mathrm{~km}$ uzaklıkta bulunmaktadır. D300 karayolu üzerindeki kavşak bölgesi, merkeze bağlı Hacıkadem Mahallesi'ne ait iki adet bağlantı yolu içermektedir. Seçilen bölge öncesinde 1şıklı trafik sistemi bulunmamakla beraber sonrasındaki 1şıklı trafik sistemi şehrin girişinde 2,5 km uzaklıktaki Dikilitaş kavşağı mevkisinde yer almaktadir.

\section{HACIKADEM KAVŞAĞI}

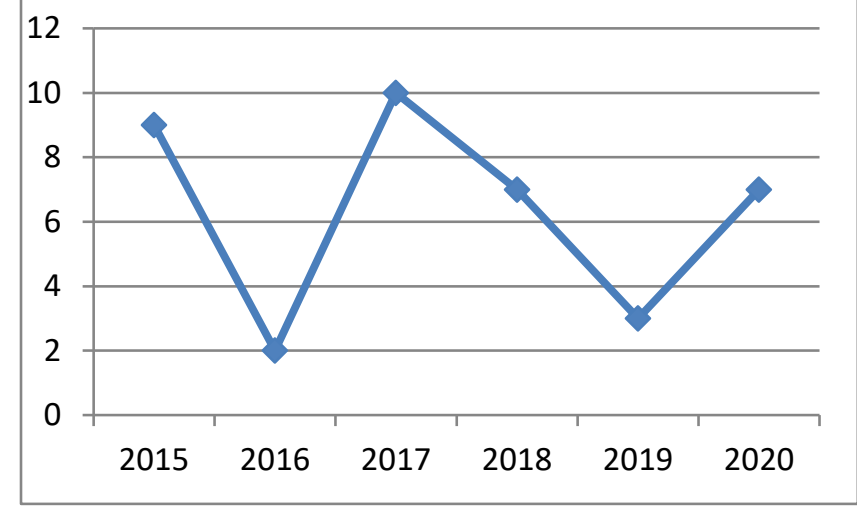

Şekil 5. Hacıkadem kavşağı bölgesi meydana gelen kazalar

Diğer bölgelerle karşılaştırıldığında kaza yoğunluğunun daha yüksek olduğu görülmektedir. Toplam kaza sayıları grafiğinde üst bölüm içerisinde yer almaktadır. D300 karayolunun il merkezinde yer alan kısmında 1şıklı trafik sisteminin olduğu ilk bölgedir. Kavşak bölgesi yolun iki tarafi içinde tepe noktasında yer aldığından 1 şık sisteminin varlığı sürücüler tarafinda fark edilememektedir. Kavşak öncesinde ve sonrasında 1şıklı sistemlerin olmaması veya uzak olması, uyarı işaretleri olmasına rağmen kaza sayılarının yüksek olmasına neden olmaktadır.

Bir diğer trafik kazası yoğunlaşan bölge olarak Şehit Yener Sunal Üst Geçidi'nin yer aldığı bölge ele alınmaktadır. Şehit Yener Sunal Üst Geçidi bölgesi için gerçekleşen kazalar Şekil 6'da gösterilmektedir. Seçilen bölge şehrin yerleşim yerleri başlangıç kısmında yer almaktadır. Öncesinde 1şıklı trafik sistemi $1 \mathrm{~km}$ uzaklıktaki Hacıkadem kavşağı bölgesinde yer alırken sonrasındaki ilk ışıklı trafik sistemi 1,5 km uzaklıktaki Dikilitaş kavşağı mevkisinde yer almaktadır.

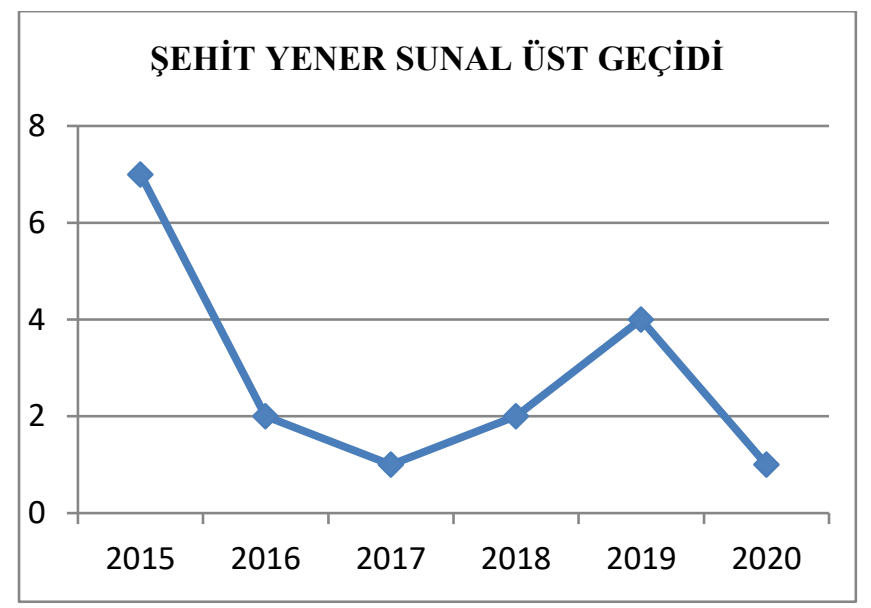

Şekil 6. Şehit Yener Sunal Üst Geçidi bölgesi meydana gelen kazalar
Bölgede yayaların karşıdan karşıya geçmesinden kaynaklanan trafik kazaları fazlaca meydana gelmekteyken inşa edilen yaya üst geçidi ve karşıdan karşıya yol üstünden geçişin engellenmesiyle kazalar önemli ölçüde engellenmektedir. Toplam kaza sayılar grafiğinde alt bölüm içerisinde yer almaktadır.

Şekil 7'de Dikilitaş kavşağı bölgesi meydana gelen kazaların yıllar içindeki durumu sunulmaktadır. Işıklı trafik sisteminin yer aldığı bölge toplam kaza sayıları grafiğinde üst bölüm içerisinde yer almaktadır. Bahsedilen ilk üç bölgeye göre daha fazla yerleşim yeri içinde yer alan bir bölgedir. Öncesindeki 1şıklı trafik sistemi yaklaşı $2,5 \mathrm{~km}$ uzaklıktaki Hacıkadem kavşağı bölgesinde yer alırken sonrasında $800 \mathrm{~m}$ uzaklıkta 15 Temmuz Mehmet Çetin Köprülü Kavşağı 1 şıklı trafik sistemi bulunmaktadir.

Ayrıca Dikilitaş kavşağ mevkisinde yer alan 1şıktan 400 m ileride battı-çıktı girişi başlamaktadır. Dikilitaş kavşağ mevkisinden sonra Batı istikametine doğru hem direkt seyahate izin veren battı-çıktı hem de 1şıklı kavşak sistemi bulunmaktadır. Bölgeye mahalle içerisinde önemli trafik yoğunluğuna sahip Barbaros Caddesi, Kuzey-Doğu istikametinden bağlanmaktadır.

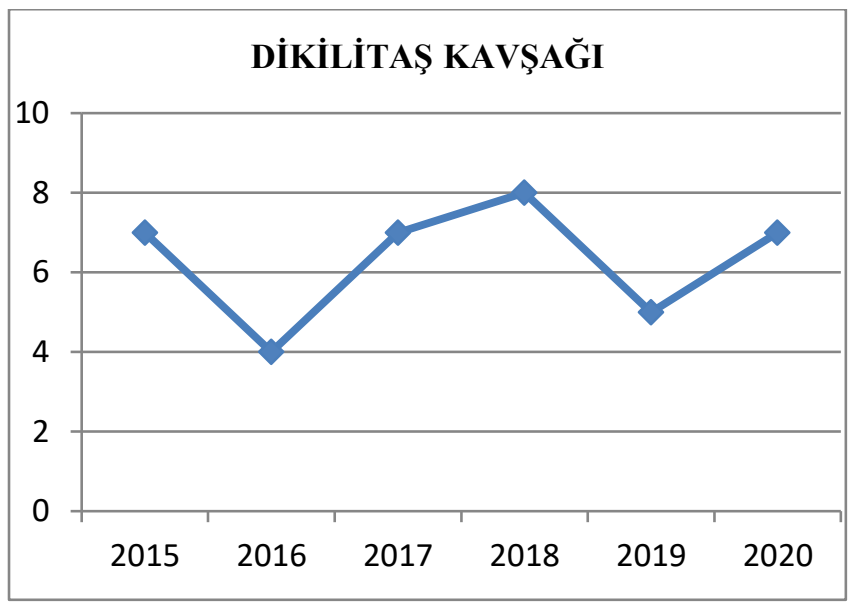

Şekil 7. Dikilitaş kavşă̆ı bölgesi meydana gelen kazalar

Bölgenin kaza sayılarında üst bölgede yer almasında yan bağlantı yollarının olmasıyla birlikte 1şıklı kavşağa iki taraftan da yüksek hızla gelişler etkili olmaktadır. Geliş yönünden 1 şı sisteminin uzak olması ve gidiş yönünde battı-çıktı yapısının mevcut olması araç hızlarının üst değerlerde olmasına sebep olmaktadir.

Şekil 8'de 15 Temmuz Mehmet Çetin Köprülü Kavşağı Öncesi 1. bölgede gerçekleşen kazalar gösterilmektedir. Bölgede öncesinde 300 m uzaklıkta Dikilitaş kavşağı 1şıklı trafik sistemi yer alırken sonrasında ise 350 uzaklıkta 15 Temmuz Mehmet Çetin Köprülü Kavşağı 1şıklı kavşak bölgesi yer almaktadır. Toplam kaza sayıları grafiğinde üst bölümde yer alan bölgelerdendir. 


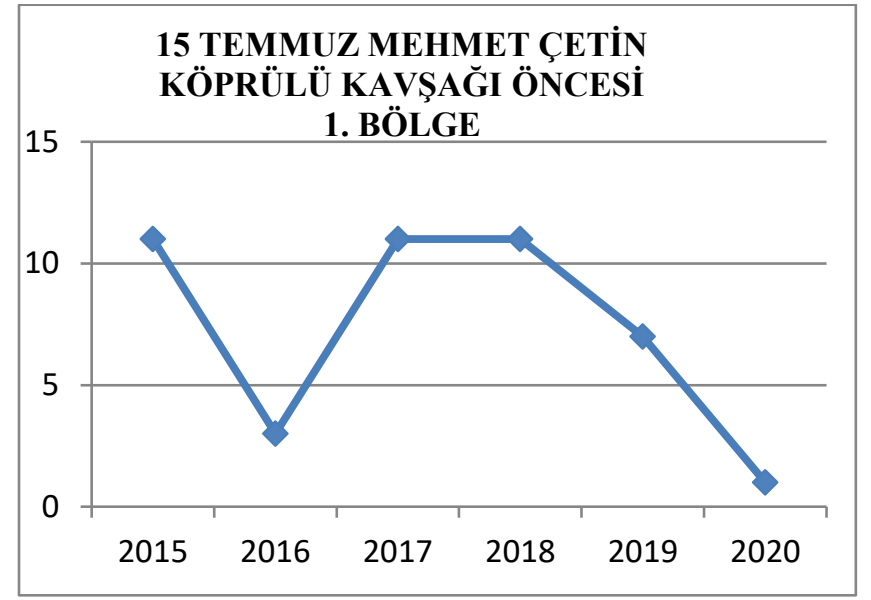

Şekil 8. 15 Temmuz Mehmet Çetin Köprülü Kavşăğ Öncesi 1. bölge meydana gelen kazalar

15 Temmuz Mehmet Çetin Köprülü Kavşağı Öncesi 1. bölgede meydana gelen kazalar sunulmakla beraber bölgenin devamında yer alan 15 Temmuz Mehmet Çetin Köprülü Kavşağı bölgesine inşaa edilen battı-çıktı yapısından dolayı kaza değerleri düşüş göstermiştir. Başlangıçta kaza sayılarının yüksek olmasında hastane bölgesi olması, yol üzerinden kontrolsüz yaya geçişi olması, yolun iki tarafından da yola katılım sağlayan yan yolların olması gibi sebepler etkili olmuştur. Yaya üst geçidi inşa edilmesi ve karşıdan karşıya yaya geçişini önleyici çit çekilmesi gibi uygulamalar kaza sayıların azalmasında için alınan önlemlerdir. Otogar bölgesine inşa edilen battı-çıktı yapısının başlangıç kısmı bu bölgenin içerisinde yer almaktadır.

15 Temmuz Mehmet Çetin Köprülü Kavşağı Öncesi 1. bölgenin devamı niteliğinde olan kaza bölgesidir. Öncesinde Dikilitaş kavşağı 1şıklı kavşak bölgesi yer alırken sonrasında 15 Temmuz Mehmet Çetin Köprülü Kavşağı 1şıklı kavşak bölgesi yer almaktadır. Şekil 9'da 15 Temmuz Mehmet Çetin Köprülü Kavşağı Öncesi 2. bölge gerçekleşen kazalar gösterilmekte olup toplam kaza sayıları grafiğinde alt bölüm içerisinde yer almaktadir.

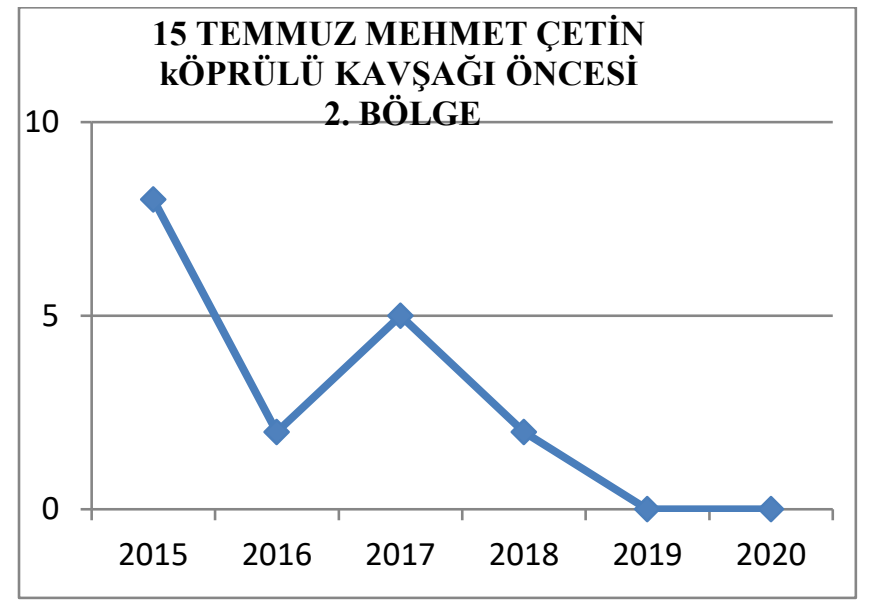

Şekil 9. 15 Temmuz Mehmet Çetin Köprülü Kavşağı Öncesi 2. bölge meydana gelen kazalar

İlk yıllarda kazaların yüksek olmasında anayolun iki tarafinda yer alan katılım yollarının etkisinden bahsedilebilir. 1 .
Bölgeye benzer şekilde yaya üst geçidi inşa edilmesi ve yaya geçişinin kontrol altına alınmasıyla kazalarda düşüşler sağlanmıştır.

15 Temmuz Mehmet Çetin Köprülü Kavşağı bölgesi gerçekleşen kazalar Şekil 10'da gösterilmektedir. Bölgede 1şıklı kavşak sistemi bulunmaktadır. Öncesinde yer alan 1şıklı kavşak sistemi $650 \mathrm{~m}$ uzaklıktaki Dikilitaş kavşağı bölgesinde bulunurken sonrasındaki 1şıklı kavşak sistemi 720 m uzaklıktaki Osmanlı Köprülü kavşağı bölgesinde yer almaktadır.

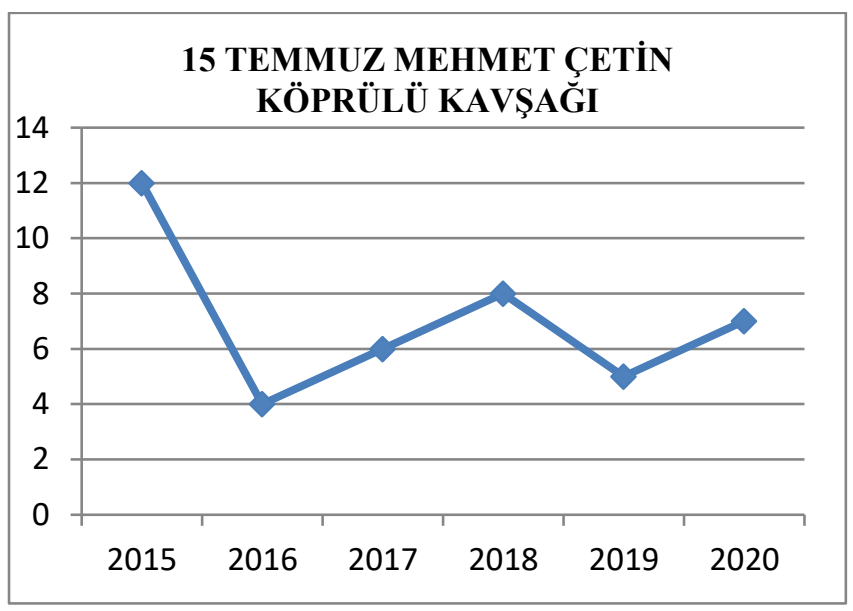

\section{Şekil 10. 15 Temmuz Mehmet Çetin Köprülü Kavşağı bölgesi meydana gelen kazalar}

Bölgede yapılan çalışma ile transit geçişi sağlayan battı-çıktı yapısı inşa edilmiştir. Şehirlerarası otobüs terminalinden çıkan araçların D300 yoluna bağlantısı bu kavşak vasıtası ile yapılmaktadır. Ayrıca kuzey ve güney doğrultusunda yüksek trafik hacmine sahip yollarda bu kavşak noktasına bağlanmaktadır. Kavşaktaki bağlantı yollarının yüksek trafik hacmine sahip olması, sonrasındaki battı-çıktı yapısında dolayı yüksek hızlara sahip araçların gelmesi gibi etkenler kaza sayılarının yüksek olmasına neden olmaktadır.

Kaza yoğunluğu olarak göze çarpan diğer bir nokta olan Osmanlı Köprülü Kavşağı öncesi bölgeye ait gerçekleşen kazalar Şekil 11'de gösterilmektedir. İki battı-çıktı bölgesi arasında yer alan bölümün 15 Temmuz Mehmet Çetin Köprülü Kavşağı battıçıktı girişine uzaklığ 350 m iken Osmanlı Köprülü Kavşağı battıçıktı girişine uzaklığı 200 m civarındadır.

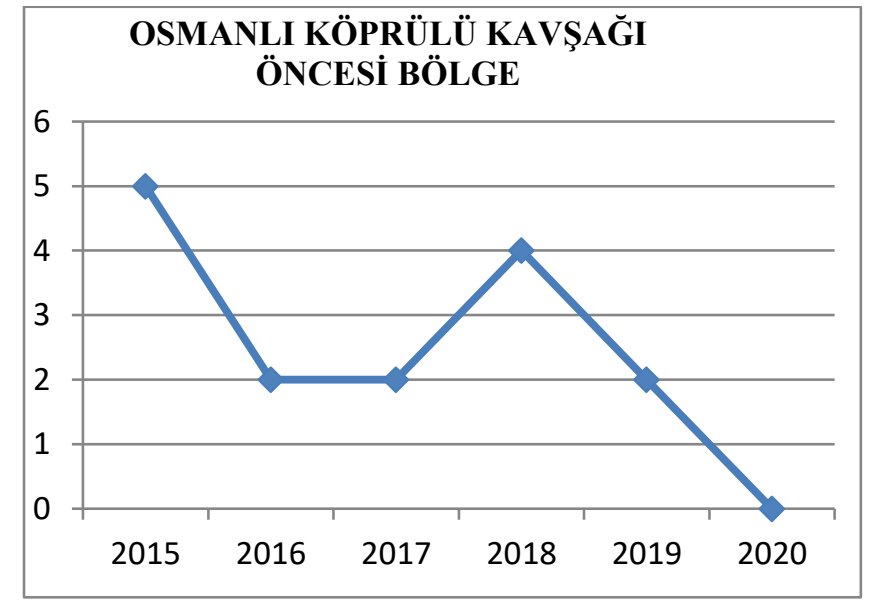


Şekil 11. Osmanlı Köprülü Kavşă̆ı öncesi bölge meydana gelen kazalar

Bölge kazalara sebep olabilecek yan katılım yolları içermektedir. Bölge toplam kaza sayıları grafiğinde alt bölüm içerisinde yer almaktadır. Kazaların meydana gelmesinde yan katılım yollarından yapılan kontrolsüz giriş ve çıkışlar etkili olmaktadır.

Osmanlı Köprülü Kavşağı bölgesi gerçekleşen kazalar Şekil 12 'de gösterilmektedir. Osmanlı Köprülü Kavşağı bölgesi öncesi 1şıklı kavşak sistemi 720 m uzaklıktaki 15 Temmuz Mehmet Çetin Köprülü Kavşağı bölgesinde bulunurken sonrası 1şıklı kavşak sistemi $550 \mathrm{~m}$ uzaklıktaki Dörtyol kavşağı bölgesinde bulunmaktadır. Kuzey-Güney doğrultusunda şehrin önemli trafik yoğunluğuna sahip yolları bu bölgeye bağlanmaktadır. Bölge öncesinde $570 \mathrm{~m}$ uzaklıkta battı-çıktı girişi ve sonrasında $450 \mathrm{~m}$ uzaklıkta Dörtyol kavşağı üst geçit köprüsü yer almaktadır.

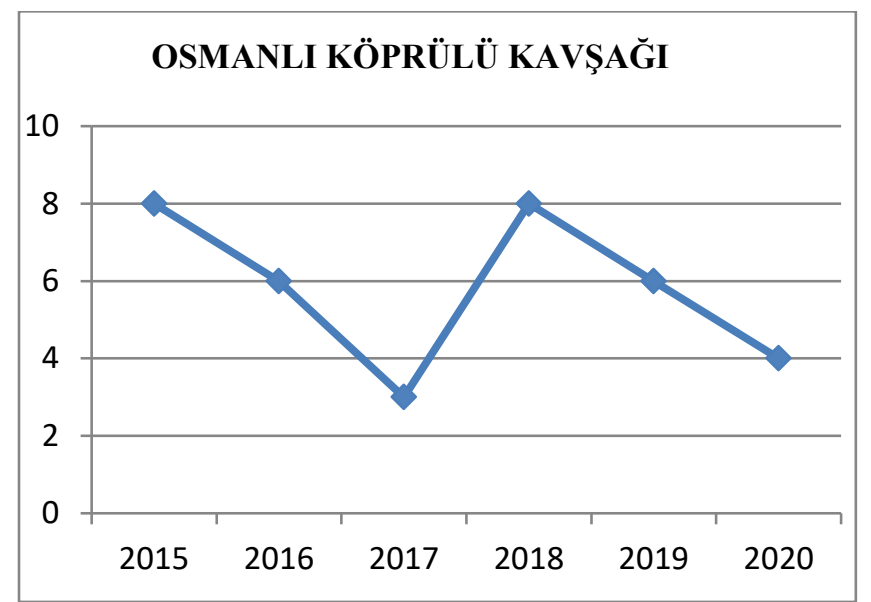

Şekil 12. Osmanlı Köprülü Kavşağı bölgesi meydana gelen kazalar

Toplam kaza sayıları grafiğinde üst bölümde yer alan bölgelerdendir. Ayrıca bölgede transit geçişe imkan veren battıçıktı yapısı inşa edilmiş vaziyettedir. Kaza sayılarının fazla olmasında trafik yoğunluğu fazla olan yolların olması etkilidir. Battı-çıktı ve üst geçit yapılarından transit geçiş yapan araçların yüksek hızlarda olması da kazaya neden olan sebeplerdendir.

Şekil 13'de Dörtyol kavşağı bölgesi gerçekleşen kazalar gösterilmektedir. Bölge öncesi 1şıklı kavşak sistemi $550 \mathrm{~m}$ uzaklıktaki Osmanlı Köprülü Kavşağı bölgesinde yer alırken sonrasındaki 1şıklı kavşak sistemi $800 \mathrm{~m}$ uzaklıktaki Belediye Cami kavşağ 1 bölgesinde yer almaktadır. Bölgede transit geçiş sağlayan araç üst geçit yapısı bulunmaktadır.

Uşak il merkezi kabul edilen Hükümet Konağı önü ile ana cadde kabul edilen İsmet Paşa Caddesi'ne giden yol ve Eşme, Ulubey ilçelerine giden bu bölgede karayoluna bağlanmaktadır. Battı-çıktı girişine uzaklığı tek taraftan $450 \mathrm{~m}$ uzunluktadır. Toplam kaza grafiğinde üst bölüm içinde yer alan bölgelerden biri de Dörtyol kavşağı bölgesidir. Bir önceki bölgeye benzer şekilde battı-çıktı yapısından transit geçiş yapan araçların yüksek hızlarda olması ve yüksek yoğunlukta trafik akışlarına sahip bağlantı yollarının olması kaza sayılarını arttıran faktörlerdir.

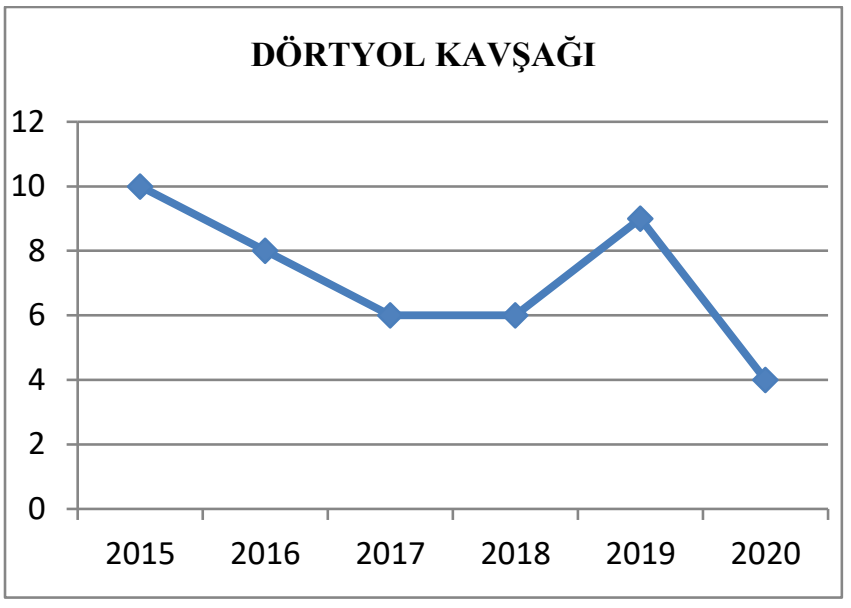

Şekil 13. Dörtyol kavşă̆ı bölgesi meydana gelen kazalar

Şekil 14'te Belediye Cami kavşağı bölgesi gerçekleşen kazalar gösterilmektedir. Işıklı trafik sistemi olarak bakıldığında 800 m öncesinde Dörtyol kavşağı bölgesi ve 900 m sonrasında Selçuklu Köprülü kavşağı bölgesi yer almaktadır. Kuzey ve Güney doğrultusundan yoğun trafiğe sahip yan yollar bağlanmaktadır. Üst geçit başlangıcı $650 \mathrm{~m}$ öncesinde yer alırken $800 \mathrm{~m}$ sonrasında battı-çıktı girişi bulunmaktadır.

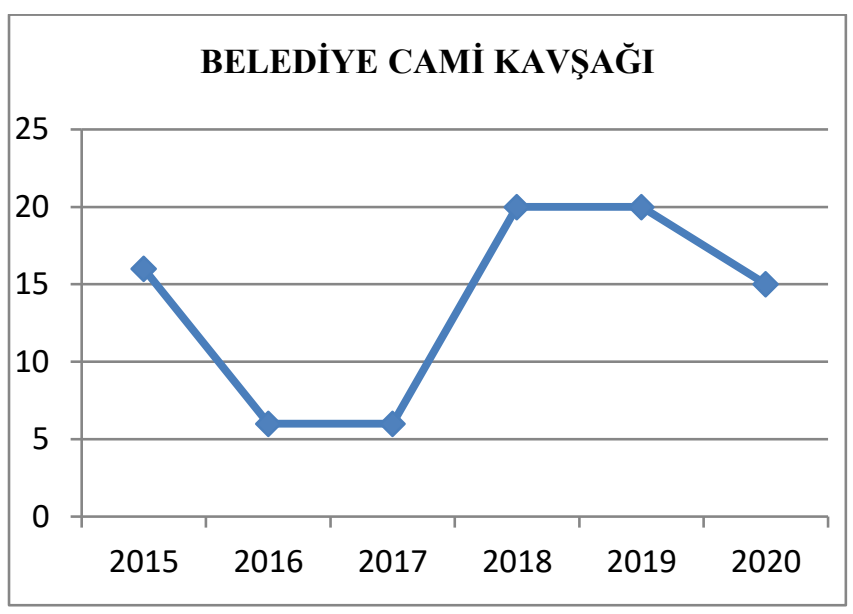

Şekil 14. Belediye Cami kavşağı bölgesi meydana gelen kazalar

İncelenen veriler doğrultusunda en fazla kazanın meydana geldiği bölümdür. Toplam kaza sayıları grafiğinde zirve değere sahiptir. Bölgede kaza sayılarının yüksek olmasında öncesinde ve sonrasında 1 şıklı trafik sistemlerinin uzak olması ve bölgenin öncesinde ve sonrasında transit geçiş sunan üst geçit ve battı-çıktı yapılarının olması önemli rol oynamaktadır.

Şekil 15’te Selçuklu Köprülü Kavşağı bölgesi gerçekleşen kazalar gösterilmektedir. Karayolunun Güney doğrultusundan Sivaslı (Uşak ilçesi)-Çivril (Denizli ilçesi)-Denizli yolu olarak bilinen yol ana yola bağlanmaktadır. Öncesinde $900 \mathrm{~m}$ uzaklıkta Belediye Cami kavşağı 1şıklı kavşak sistemi yer alırken sonrasında 1300 m uzaklıkta 1 Eylül Sanayi kavşağı 1şıklı kavşak sistemi yer almaktadır. Bölgede inşa edilmiş battı-çıktı yapısı bulunmaktadır. 


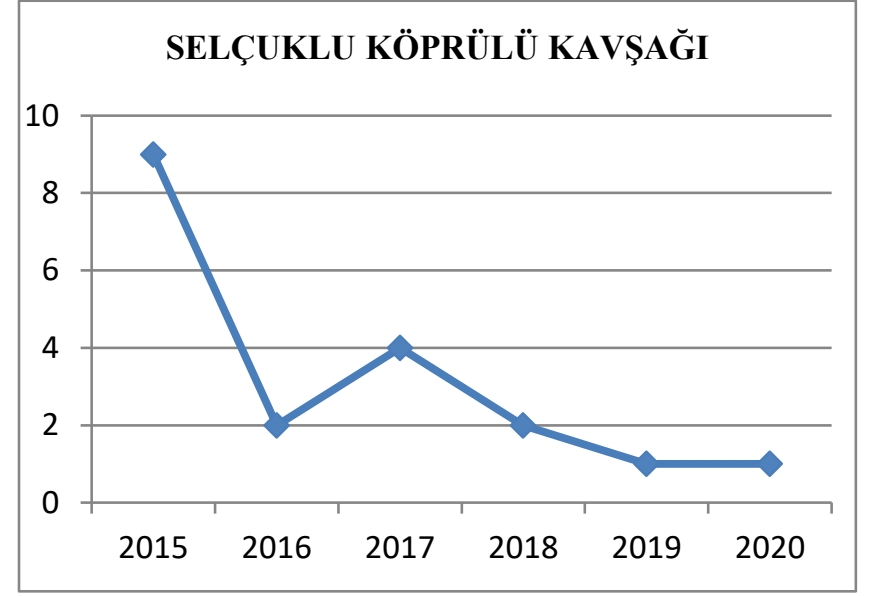

Şekil 15. Selçuklu Köprülü Kavşağı bölgesi meydana gelen kazalar

Toplam kaza sayıları grafiğinde alt bölümde yer alan bölge, inşa edilen battı-çıktı sonrası kaza sayılarında düşüş göstermiştir. Şekil 15'te gösterilen Selçuklu Köprülü Kavşağı bölgesi meydana gelen kazalar grafiği son yıllarda oldukça azalmıştır.

1 Eylül Sanayi kavşağı bölgesi gerçekleşen kazalar Şekil 16'da gösterilmektedir. Öncesinde $1000 \mathrm{~m}$ uzaklıkta battı-çıktı girişi yer almaktadır. Işıklı trafik sistemlerine uzaklıkları, $1300 \mathrm{~m}$ öncesinde Selçuklu Köprülü Kavşağı bölgesine ve $850 \mathrm{~m}$ sonrasında Uşak Eğitim ve Araştırma Hastanesi kavşağı bölgesi olarak ölçülmektedir. Bölgeye Kuzey tarafından alışveriş bölgesi ulaşım yolu bağlanırken Güney tarafından oto sanayiye ulaşım yolu bağlanmaktadır.

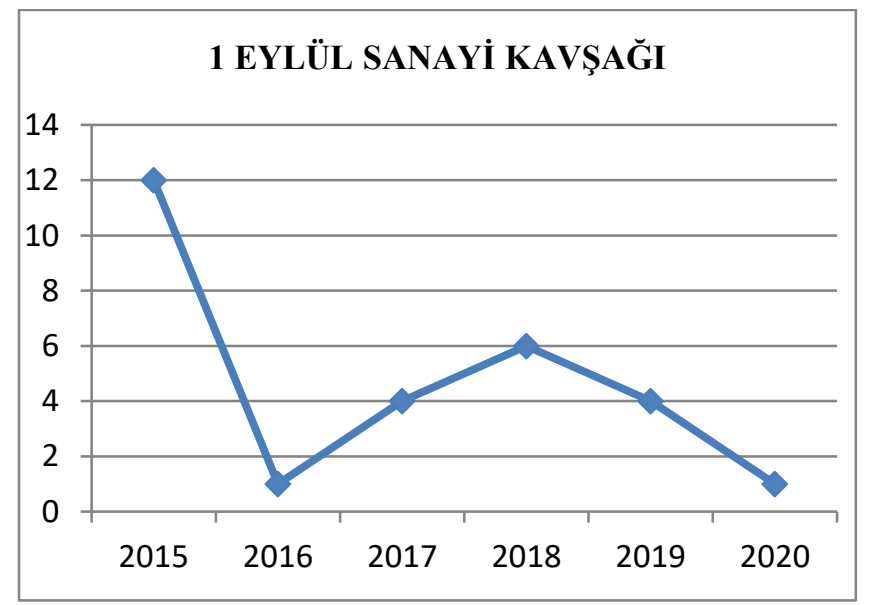

Şekil 16. 1 Eylül Sanayi kavşağı bölgesi meydana gelen kazalar

Toplam kaza sayıları grafiğinde orta bölümde yer alan ikinci bölgedir. Kazaların oluşmasında, öncesinde ve sonrasında yer alan 1 şılı sistemlerin uzak olması dolayısıyla bu bölgeye gelen araçların yüksek hız değerlerine ulaşabilmeleri sonucu 1 şıta duramama problemi etkili olmaktadır.

Uşak Eğitim ve Araştırma hastanesi kavşağ gerçekleşen kazalar Şekil 17'de gösterilmektedir. Bölgede yer alan kavşak eğitim araştırma hastanesi, emniyet müdürlüğü, adliye ve 2 adet okul olmak üzere kamu kurumlarına ulaşım sağlayan önemli bir geçiş noktasıdır. Hastane bölgesinin öncesinde $850 \mathrm{~m}$ uzaklıkta 1 Eylül Sanayi kavşağı bölgesi 1şıklı e-ISSN: 2148-2683 kavşak sistemi bulunurken sonrasında 1 şılı trafik sistemi bulunmamaktadır. D300 karayolunun il içerisindeki kısmında son 1şıklı trafik sistemi burada bulunmaktadır. Toplam kaza sayıları grafiğinde orta bölümde yer alan bölgeler arasındadır. Bölge sonrasında 1 şık sistemi olmayışından ve bölge öncesinde uzak mesafede 1şık sistemi olmasından dolayı yüksek hızlarda araçların gelmesi kazalara sebep olan temel durumdur. Kamu kurumlarının varlığından dolayı kavşağın trafik yoğunluğu oldukça fazladır. Yoğunluğun verdiği trafik sıkışıklıkları sürücüler tarafından trafik güvenliğini tehlikeye atacak davranış sergilenmesine ve kazaların meydana gelmesine ortam hazırlamaktadır.

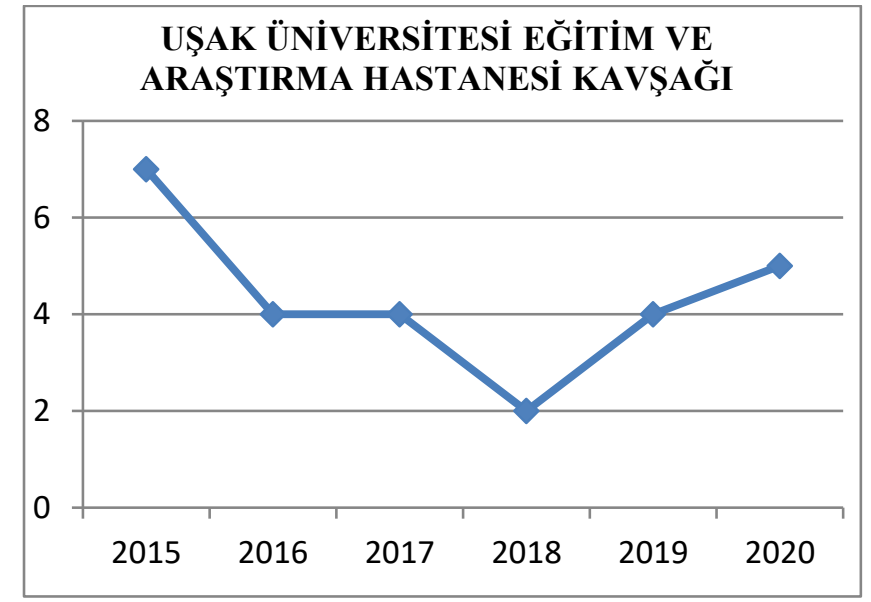

Şekil 17. Uşak Üniversitesi Eğitim ve Araştırma hastanesi kavşă̆ bölgesi meydana gelen kazalar

Şekil 18'de Havalimanı kavşağı bölgesi gerçekleşen kazalar gösterilmektedir. Bölge öncesinde 2,7 km uzaklıkta Uşak Eğitim ve Araştırma hastanesi bölgesi 1şıklı kavşak sistemi yer almaktadır. Havalimanı kavşağı bölgesinde 1şıklı trafik işareti olmayan kavşak olmakla birlikte sonrasında da 1 şıl 1 trafik sistemi bulunmamaktadır. Kuzey ve Güney doğrultudan merkeze bağlı İkisaray Mahallesi ve Bozkuş Köyü'ne bağlantı yolları birleşmektedir.

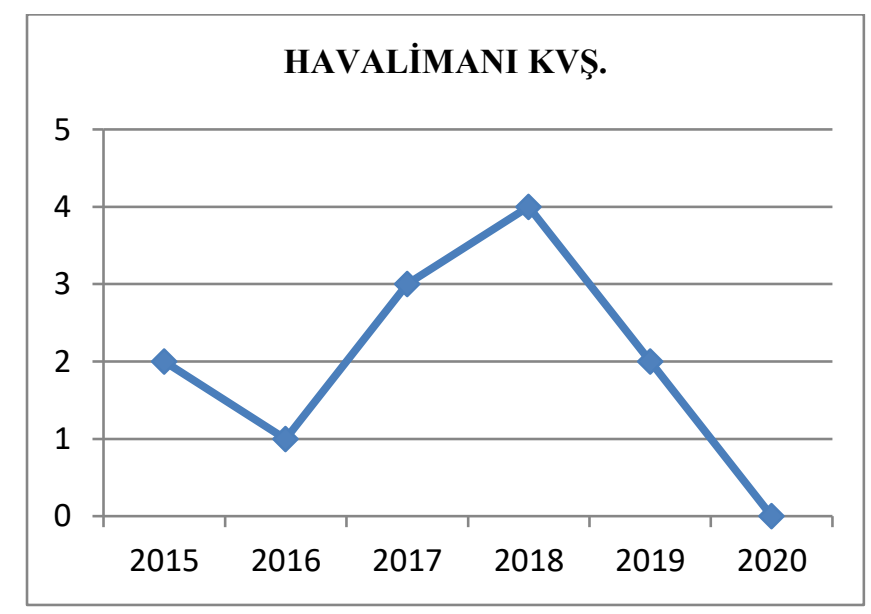

Şekil 18. Havalimanı kavşağı bölgesi meydana gelen kazalar

D300 karayolu için talep veriler doğrultusunda ele alınan son bölgedir. Toplam kaza sayıları grafiğinde alt bölümde yer alan son bölgedir. Işıklı trafik sistemi olmayışından dolayı ana yola yapılan 
kontrolsüz geçişler ve bölgeye gelen araçların yüksek hız değerlerine sahip olması kazalara sebep olmaktadır.

\section{Sonuç}

Günden güne artan araç sayısı beraberinde trafik kazalarında da artışlar görülmesine neden olmaktadır. İnsan faktörünün kazaların temel nedeni olmasının yanı sıra sürücü kusurlarının da temelinde aşırı hız etkeni bulunmaktadır. Trafik güvenliğinin sağlanamaması durumunda oluşan trafik kazaları sonucunda ölümlü, yaralanmalı ve maddi hasarlı kazalar meydana gelmekle birlikte kaza sonrası kazaya karışanlar üzerinde psikolojik yönden olumsuz ruh halleri de ortaya çıkmaktadır.

Bu çalışmada Uşak İli içerisindeki D300 karayolu üzerindeki bir kesitte meydana gelen kazalar, 15 ayrı noktada incelenmiştir. İncelemeler neticesinde Hacıkadem Kavşağı, Dikilitaş Kavşağı, 15 Temmuz Mehmet Çetin Köprülü Kavşağı ve öncesi 1. Bölüm, Dörtyol Kavşağı ve Belediye Cami Kavşağında kaza sayılarının diğer bölgelere göre daha fazla olduğu saptanmıştır. Genel kaza sebepleri olarak yüksek hız, yan bağlantı yolları, kontrolsüz yaya geçişi ve yol geometrisi gibi etkenler öne çıkmaktadır.

Kaza bölgelerinde kazaları gidermek amacıyla yeni yap1 imalatları(battı-çıktı uygulaması), üst geçit uygulamaları, yaya geçişini kontrol altına alma amacıyla orta kaldırıma set çekme uygulamaları, yol geometrisi düzenleme gibi uygulamalar geliştirildiği görülmüştür.

Kaza sayısı yüksek olan Hacıkadem Kavşağı, Dikilitaş Kavşağı, 15 Temmuz Mehmet Çetin Köprülü Kavşağı ve öncesi 1. Bölüm, Dörtyol Kavşağı ve Belediye Cami Kavşağı bölgeleri için alınan önlemlerin etkinliğini arttırmak, ölümlü-yaralanmalımaddi hasarlı kazaları önlemek, trafik güvenliğini arttırmak adına eksikliklerin tespit edilerek bu eksikliklere uygun çalışmalar yapılmalıdır. Trafik güvenliği yönünden riskli olan noktalar için trafik güvenliğini arttırmak adına hız sınırlandırma, alt geçit, üst geçit, yol geometrisinde iyileştirme gibi ilave uygulamalar ele alınmalıdır. Mevcut uygulamaların düşünüldüğünde bu uygulamaların etkinliğini arttırmak adına en etkili yöntem olarak hız sınırlandırma ön plana çıkmaktadır. D300 karayolunun trafik yoğunluğunun yüksek oluşu, kasis ve trafik ışığı gibi hız sınırlama yöntemlerinin tercih edilmesini uygunsuz kılmaktadır. Dolayısıyla son yıllarda kullanımı yaygınlaşan ortalama hız koridoru uygulaması tercih edilmelidir. $\mathrm{Bu}$ sayede trafik güvenliğinde artış sağlanmış olup alınan tedbirlerin etkinliği artarak ölümlü, yaralanmalı ve maddi hasarlı kazaların önlenmesi sağlanmış olacaktır.

\section{Teşekkür}

Uşak Belediyesi ve Uşak Emniyet Müdürlüğü, Trafik Tescil Ve Denetleme Şube Müdürlüğü'ne vermiş oldukları destek ve katkılardan dolayı teşekkür ederiz.

\section{Kaynakça}

Acar, N. (2009). Aşırı Hızın Trafik Kazalarına Etkisi. Erişim Tarihi: 23.05.2021. http://www.caginpolisi.com.tr

Aldoğan, A. (1991). Trafik Kaza İstatistiklerinin Değerlendirilmesi ve Kazaların Azaltılmasında Bakanlı̆̆ımızca Hazırlanan Yeni Uygulamalar ve Alınması
Gerekli Kısa ve Uzun Vadeli Teklif ve Öneriler. Trafik Şurası, Ankara.

Aydın, M.M. (2017). Şehir İçi Kavşaklardaki Geometrik Disiplinsizliğin Optimize Edilerek Irdelenmesi. Doktora Tezi, Fen Bilimleri Enstitüsü, Akdeniz Üniversitesi, Antalya.

Cavdar, A., Uçar M. \& Kılıçaslan I. (2008). Trafik Kazalarına Sebep Olan Yüksek Hız Kusurlarının Denetimi ve Aktif Güvenlik Sistemler ile Kontrolü. Gazi Üni. Müh. Mim. Fak. Der. 23(1), 187-198.

Civcik, L. \& Koçak, S. (2020). Travel Time Prediction with Bluetooth Sensor Data in Intelligent Traffic System (ITS). EJOSAT-European Journal of Science and Technology, (Special Issue), 522-529.

Elvik, R. (1999). Cost-Benefit Analysis of Safety Measures for Vulnerable and Inexperienced Road Users. Institute of Transport Economics, TQI Report 435/1999, Oslo.

Güneş, F., Bayraklı, S. \& Zaim, A.H. (2020). Sinyalize Bir Kavşakta Oluşan Trafik Akımının Kuyruk Teorisi ile Performansının İncelenmesi. EJOSAT-Avrupa Bilim ve Teknoloji Dergisi, (19), 56-65.

Goldenbeld, C. \& Van Schagen, I. (2005). The Effects Of Speed Enforcement With Mobile Radar On Speed And Accidents: An Evaluation Study On Rural Roads In The Dutch Province Friesland. Accident Analysis \& Prevention, 37(6), 1135-1144.

Ilgaz, A. \& Saltan, M. (2017). A Case Study on Speed Behavior Determination Via Average Speed Enforcement at The Akdeniz University Campus Area. International Journal of Engineering and Applied Sciences, 9 (3), 22-35.

Ilgaz, A. (2017). Ortalama Hız Sınırı Uygulamasının Sürücülerin Hiz Profilleri Üzerindeki Etkilerinin Analizi: Akdeniz Üniversitesi Kampüsü Örneği. Doktora tezi, Süleyman Demirel Üniversitesi Fen Bilimleri Enstitüsü, Isparta.

Jones A. P., Sauerzapf V. \& Haynes R. (2008). The Effects Of Mobile Speed Camera Introduction On Road Traffic Crashes And Casualties In A Rural County Of England. Journal of Safety Research, 39(1), 101-110.

KGM. (2019). Trafik Kazaları Özet. Erişim Tarihi: 22.05.2021. https://www.kgm.gov.tr/Sayfalar/KGM/SiteTr/Trafik/Trafik KazalariOzeti.pdf

Ng, C.F. \& Small, K.A. (2012). Tradeoffs Among Free-Flow Speed, Capacity, Cost, And Environmental Footprint In Highway Design. Transportation, 39(6), 1259-1280.

Şahin, Ö. (2004). Hız Denetiminde Otomatik Video-Radar Sistemlerinin Uygulanabilirliği. Doktora Tezi, Fen Bilimleri Enstitüsü, Süleyman Demirel Üniversitesi.

Tenekeci, G. (2019). Computation and Assessment of Environmental Emissions Resulting from Traffic Operations at Roundabouts. EJOSAT-European Journal of Science and Technology, (Special Issue), 130-145.

Trafik Tescil Ve Denetleme Şube Müdürlüğü, (2020). Kaza Sonucuna Göre Kaza Istatistikleri. Uşak.

Türkiye Şoförler ve Otomobilciler Federasyonu, 1997, Ticari Taşıt Şoförleri-Trafik Polisi İlişkileri. Ankara.

Ulaştırma Özel İhtisas Komisyonu Raporu Trafik Düzeni (2001). Karayollarında Can Güvenliği Alt Komisyonu Raporu. Sekizinci Beş Yıllık Kalkınma Planı, ISBN 975-19-2723-4, Ankara.

Vadeby, A. \& Forsman A. (2014). Speed Distribution And Traffic Safety Measures. Transport Research Arena (TRA), 14-17 April 2014, Paris. 